12th LUMEN International Scientific Conference Rethinking Social Action. Core Values in Practice | RSACVP 2019 | 15-17 May 2019 | lasi-Romania

\title{
Tradition - Innovation in the Lyrics of Besik Gabashvili, a Georgian Poet of the Renaissance Period
}

\author{
Tamar GOGOLADZE, Ketevan BARBAKADZE
}

$\underline{\text { https://doi.org/10.18662/lumproc. } 159}$

How to cite: Gogoladze, T., \& Barbakadze, K. (2019). Tradition Innovation in the Lyrics of Besik Gabashvili, a Georgian Poet of the Renaissance Period. In C. Ignatescu (ed.), 12th LUMEN International Scientific Conference Rethinking Social Action. Core Values in Practice, 15-17 May 2019, Iasi - Romania (pp. 126-132). Iasi, Romania: LUMEN Proceedings. https://doi.org/10.18662/lumproc.159 


\title{
Tradition - Innovation in the Lyrics of Besik Gabashvili, a Georgian Poet of the Renaissance Period
}

\author{
Tamar GOGOLADZE ${ }^{1}$, Ketevan BARBAKADZE ${ }^{2}$
}

\begin{abstract}
The lyrics of Besik (Besarion) Gabashvili (1750 - 1791), a poet of the royal court and a diplomat was quite popular in the Georgian poetry of the XVIII - XIX centuries. Due to Georgian political events his fate got somehow related to the city Iasi, Romania, where the poet is buried. In the period of activity of Georgian - Romanian relations, in the 70s of the XX century, a collection of poems "Armies of Sadness", where the poet's 25 poems are included, was translated into Romanian language by Georgian (G. Jinjikhashvili and L. Kochladze) and Romanian (Dumitru M. Ion) translators.

Thus, we decided to focus on the lyrics of a famous poet Besarion Gabashvili, who is very popular among the Georgians and more or less familiar to the Romanians. He was the poet who finished the love lyrics, dictated by Eastern motifs, and marked with traditional Georgian signs; the lyrics, which is full of new metaphors, inspired to seek real, specific poetic faces from the "book-mannered" expression of love. The novelty, as the research showed us, is represented by an amazingly proper, bighly artistic poetic word. Its sad disposition appeared to accompany the lyrics of Romanticists as well, and it did not lose its importance up to the present day. In the XX century, the lyrics of Besarion Gabashvili was taught in the secondary school for 70 years, and in the higher institutions bis works are an integral part of the education course "Georgian Literature 1".

In the current paper we focus on his lyrics in the context of world literary processes.
\end{abstract}

Keywords: Besarion Gabashvili; Love Lyrics; Verse Poetic Form "Besikuri”.

\footnotetext{
${ }^{1}$ Prof. Dr., GSTU Faculty of Humanities, Gori University, Georgia, Doctor of Philological Sciences, tamilagogoladze@gmail.com

2 Assoc. Prof. Dr., GSTU Faculty of Humanities, Gori University, Georgia, Doctor of Philological Sciences.
} 
Tamar GOGOLADZE et al. | Lumen Proceedings 9 | RSACVP2019

\section{Introduction}

The creative work of a poet Besarion (Besik) Gabashvili (1750-1791), an outstanding representative of Georgian literature is notable for two reasons:

1. The influence of novelties and standards of eastern poetry was over in his lyrics and appeared novelties which were connected to the traditions of western culture.

2. The style and form his creative work later influenced on the lyrics of Georgian romantic poets of the XIX century.

Characterizing Besiki's creative work on different levels of Georgian literature (XVIII, XIX, XX) appeared diversity of viewpoints of literary researchers. In spite of that he still remains one of the popular Georgian poets which is conditioned by highly esthetical features. The fact is noteworthy that due to disagreement with the Kartl-Kakheti royal court, the poet fugitive in Western Georgia, continued working on the diplomatic platform and met the end of hislife in the town of Iasi in 1791. According to S. Tsaishvili in 1949 N. Berdzenishvili and O. Gigineishvili visited Besili's grave in the town of Iasi, In the yard of the Temple of Golia they found a tombstone, which was taken from the abandoned cemetery of the tricolor of the Bulgarian temple. Epitaph told us (by Russian and Greek inscriptions) that Besarion Gabashvili died on January 24, 1791. Now this tombstone could be in the Historical Museum of Moldova, in the town of Iase (according to Valerian Macharadze).The scientific worker of the museum, Alexandru Andronic sent the photocopy of the encryption of the tombstone. Romanian poets translated his lyric and in 2019 his monument was opened in the central location of Iasi, which encouraged further development of Romanian-Georgian literary contacts.

\section{Problem Statement}

As it was mentioned in the introduction, since the XVIII century diversity of attitudes was noted in the Georgian literary or scientific reviews towards the literary works of Besarion (Besik) Gabashvili, the poet of a renaissance epoch. Despite the political events going within the Royal court, the poet became popular during his life and his poems (especially his love lyrics) were studied by heart, were sung and were spread by manuscripts as there was a lack of publishing a book or periodic.

The poet, Besik, was born in the family of Zakaria Gabashvili, a cleric who was close to the scribe and the royal court, has received high 
education of that time. The reason for the popularity of his poems was the wonderful samples of his love lyrics ("The Garden of the Sorrow", "Queen Anast", "Tano Tatano" etc.) and that the lines addressed to real peopleno longer wereconsideredas sin, as expressing the romantic feeling "in Europe it is not a shame, it means more love to each other " [1]. According to the researchers (G. Leonidze), such personally addressed lyric could have become the reason of his expelling from the Royal court but the evaluation of his poetry in modern times was quite positive till the first half of the XIX century. The researcher S. Tsaishvili brings quotations by Ioane Batonishvili "Besarion Gabashvili was an experienced scientists and alien poet, like Rustaveli, who wrote many pleasant verses," [2]. As far as Besiki knew Persian language (which was almost obligatory for the educated Georgians), he completely gave Georgian features to Persian-Arabic "Mukhambazi" or "Mustazads" and got new forms to the native poetry. "Besiki's name became a kind of etalon among his contemporaries and the huge number of followers appeared" [2]. Such can be considered the wellknown romantic poet of the 19th century Alexander Chavchavadze (17861846). The great part of his creations follow the forms and genres of the latest past (Besik, Saiatnova and others) such as "Mukhambazi" and Mustaadai, Kaifa and Gafi, Baia and Tejnis "[3] - notes the researcher Irakli Kenchoshvili. And though Alexander Chavchavadze himself is a true follower of Europeanism, he was not able to avoid the influence of Besik's poetry. Another researcher, Davit Gamezardashvili notes: "A. Chavchavadze with the forms of his poems and vocabulary is directly related to the Georgian writings of the renaissance period ... It is often difficult to differentiate A. Chavchavadze's poems from Besiki's or other poets' poems of this period"[4]. In the XIX century, when the writers of the "independence lost" countryare more disturbed by national issue, writing resembling and using the writing forms of Besiki or the author of "Vardbulbuliani" (Poet Teimuraz I), is not a novelty of romanticism, and in the epoch of establishing realism. Though the aesthetics of his lyric and form (14-syllabled so-called Besik-like) still remains in Georgian poetry, which is accepted in the beginning of the 20th century by Georgian symbolist poets, united in the literary group of "Tsisperkantseli"). TitsianTabidze in his poem "Chaldea Towns" says: "I put Gaphizi's (eastern poet) rose in a Prudhomme's vase, in Besik's garden; I am planting Baudelaire's evil flowers". (Line is ours - TG, etc.). According to S. Tsaishvili, it is a hint on the Georgian symbolists' attempt of the synthesis of Eastern and Western cultures.

S. Tsaishvili concludes: "But this time for us the fact that Besiki is presented in a context that clearly shows Titsian's point of view, is essential. 
Besarion is reflected as adapt of Oriental, namely, the Persian literature "[2]. However, the researcher sees this more in love lyric (like other researchers), and that seems to be just as well "[2].

In the XX century, during the whole "Soviet epoch" the Eastern influence on Besiki, and the assessment of the "oldest" prevails, which itself was constituted by the requirements of the "Communist" Code. However, it is worth noting that Besiki's works had been publishedand even taught in the Soviet schools for the period of a century and half. For instance: according to the program project in Georgian literature, published in the journal "Georgian Language and Literature", in 1989, the main list of the IX class included the works of Besiki's creations ("Tano - Tatano "and" The Garden of Sadness "," For Aspindza") have allocated 3 hours, while the mandatory literature includes" Besiki's biography. "General Overview of his creative works", in which the student should focus on the means of artistic expressions of Besiki's poems. [5].

Since 2000s and later, after involvement in the Bologna process, the Ministry of Education has removed the poetical works of Besiki from the program. However, the popularity of some of his poems continues in Georgian literary or in the theatrical spheres (in a play "White Flags" by N. Dumbadze).

It is evident that education workers and theorists have focused on the understanding of the creations of other Georgian and foreign writers that are necessary for the development of intellect and skills of modem generation. Therefore, in the presented article, we aim to show the main problems of tradition and innovation in the creative work of Besiki, also by advancing the genesis of Georgian literature, which illustrates the diverse completion of Georgian literature together with European literary processes, (illustration of Besarion (Besik) Gabashvili's creative works are the exact illustration of this).

\section{Research Questions/Aims of the reaserch}

As far as the assessment of Georgian poet Besarion Gabashvili's creative work generally is more or less odious in the opinion of the researchers of the previous century (XX c.), the following issues should be discussed:

1. What is the significance of Besiki's creative work (especially love lyric) based on the traditions of Georgian poetry and what is it from historical point of view that demonstrates the continuation of the Georgian love lyric direction? 
2. What novelty is in Besiki's poetry from the view of the $\mathrm{XX}$ century and what is its innovation?

3. Is the important to reevaluate the creative work of Besiki for a clear understanding of the development of world literary processes?

Objective: to clarify the mentioned issues in the theoretical aspect (with the verification of the researchers' views), and to outline the development of geneses of the Georgian literature by analyzing Besiki's creative work.

Our article presents the discussion as a hypothesis: Is it necessary to re-evaluate and revise the poetry of the "renaissance epoch" (Baroque) for the development of modern Georgian poetry.

\section{Research Methods}

The article will use the comparison and typology methods of the researchers' ideas and views.

\section{Discussions}

Based on the researchers' opinion in the study of Besik's work, it became evident that Besiki's lyric perfected and developed the main idea of "The Knight in the Panther's Skin" by the XII century genius poet Shota Rustaveli - a new moral-aesthetic model of love could have been made available by the artistic reflection to the contemporaries by a poem, which brought its popularity that is now considered as a sample of renovating traditional model.

It was well demonstrated by two researchers Sargis Tsaishvili and David Lashkaradze. S. Tsaishvili presents the viewpoint of a well-known researcher of old Georgian literature Korneli Kekelidze, who considers it as an expression of Eastern Sufism, and states that "it is possible to speak about an external analogy here, because such a course in the Georgian writings is developed on the views based on the theoretical mysticism of Christianity."'[2]. He thinks that the Eastern Sufism is only a "mystical allegory". So, watching beautiful objects and representing them by precious symbols in Besiki's works is an attempt of making a writer's biography into a poem by means of metaphors. According to S. Tsaishvili here, tradition and innovation are combined and presented as a new feature and not as a result of influence of a "Oriental Poetry"

It is necessary to note that the epoch of Besik is a kind of cultural influences: due to political situation the country seeks ways to get closer to 
European countries, at the same time retreats the process of searching for love and pleasure in oriental poetry and innovations by introducing Europeanism demands for establishing itself. In this regard, the researcher David Lashkaradze mentions a poet, more or less aware of European literature (who has read the famous examples of ancient literature, famous Greek philosophers, "Velisariyan", Marnelet "Gill Blazz", etc.): "Besik (Besarion) Gabashvili's creative work deserves great interest from the point of making Georgian Literature like a European literary taste. His creative work is raised on the best traditions of old Georgian writers which are organically linked with the XIX century modern Georgian Literature. "[6]. But here, Lashkaradze draws special attention on the names of European writers or heroes established in Besiki's lyrics, yet the form of poem cannot be considered as European influence.

The 21st-century researcher Tamar Barbakadze says about the development of poetical form: "In the history of Georgian poetry there is a proper place for studying literature verification (Akaki Khintibidze, D. Kobidze, Gr. Robakidze) ... European political innovations should be dissolved in the nearest oriental voice and intonation "[7].

"Combinative poetry, which is equally appealing and interesting for European and Oriental poetry, is basically a tedious melodic search in Besik's version" [7].

According to A. Khintibidze, Besik's poetic heritage (47 verses and 3 poems) "gives us 68 poetic forms."

"Besiki-like measurement" takes place just in his poems: It enhanced Georgian poetic meter with 14-syllabic type-so called "Besiki-like" $(5,4,5)$, which is most vividly portrayed in his poem "Tano - Tatano". Here the reflection of the tradition combined with contextual point is presented in a new form, so called "Besiki-like".

Thus, we believe that Besiki's creative work, which still demands the new perspective of the researchers, is a pattern of synthesis of tradition and innovation.

\section{Conclusions}

Artistic development of the Georgian poet Besarion (Besik) Gabashvili (Here is the main focus of the painting lyric) is the creative development of the XII century masterpiece. Rustaveli "The Knight in the Panther's Skin". The main topic - the moral-aesthetic model of love and, in our view, the conclusion of the researchers gives us the basis to conclude that it is a sample of active process of development of Georgian lyric. 
Besik's poetry is a synthesis of tradition and innovation. From the $\mathrm{XX}$ century, it is based mainly on the researchers of the previous century, although it is important in terms of the verification of the nature of the novelty. In the opinion of the researcher Irma Ratiani, "Georgian Literature and World Literary Process" is referenced: "In the same period, the poetry of a gifted poet Besik Gabashvili, despite the poet's positive attitude to oriental versions of the poetry, striving to the Western stylistic experiment is vividly felt".[8]

We believe that the re-study of Besik's creative work in this regard, raises the hypothesis to be discussed in the light of modernity and in the context of the development of the European lyrics of the same epoch, which, of course, is motivated by the typological analysis of the poetry of this epoch of Georgian literature of the XVIII century, namely, Besik Gabashvili is an outstanding representative.

\section{References}

[1] Batiashvili I. ChEC.F.S 5367:1: (in Georgian)

[2] Tsaishvili S. Gwacli Besarion Gabashvilisa (The heritage of Besarion Gabashvili). Georgian Language and Literature at School. 1983; \#2:50,51,52,53,55,58 (in Georgian)

[3] Kenchoshvili I., Cinasitkwaoba (Foreword). Aleksander Chavchavadze, Tchzulebebi (Works). Tbilisi: Merani; 1986:6 (in Georgian)

[4] Gamezardashvili D. From the history of Georgian literature and criticism. t.3: Tbilisi; Soviet Georgia:187 (in Georgian)

[5] The Project of Georgian Literature. Georgian Language and Literature at School: 1987, \#1-4: 352-353 (in Georgian)

[6] Lashkaradze D. The Problem European influence in Georgian literature. Tbilisi: Soviet Georgia 1977:147 (in Georgian)

[7] Barbakadze T. Verification System of Besarion Gabashvili. Sdjani. 2000, \#14:102,103 (in Georgian)

[8] Ratiani I. Georgian Literature and World Literary Process: Tbilisi: Chveni Mcerloba:2012, \#23:10 (in Georgian) 